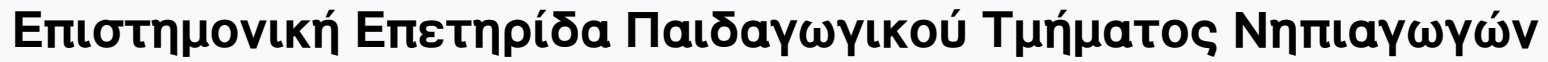

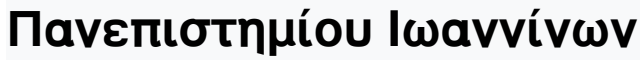

Tóm. 11, Ap. 1 (2018)

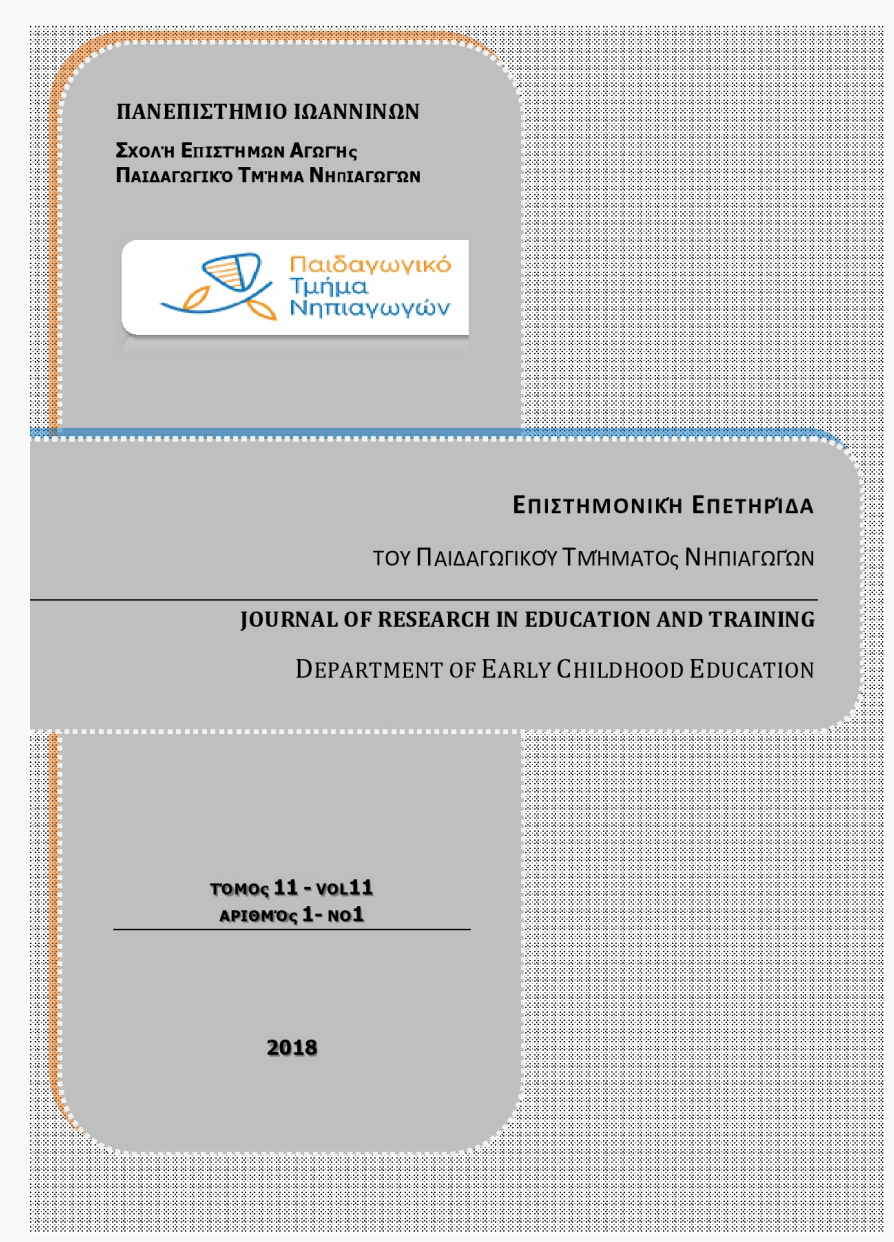

Recalling the past : "The voice of objects" in three short stories for young readers written by Angeliki Varella

Dionisia Margariti

doi: $10.12681 /$ jret.14977

Copyright $\odot$ 2018, DIONISIA IOANNIS MARGARITI

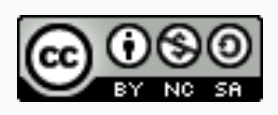

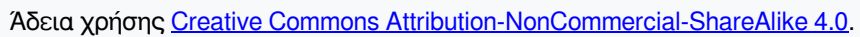

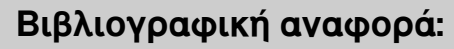

Margariti, D. (2018). Recalling the past: "The voice of objects" in three short stories for young readers written by Angeliki

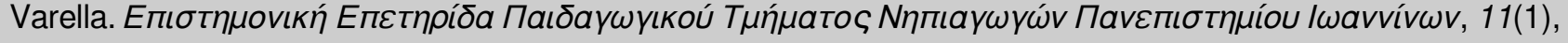
136-153. https://doi.org/10.12681/jret.14977 


\title{
Recalling the past: "The voice of objects"' in three short stories for young readers written by Angeliki Varella
}

\section{Dionisia Margariti}

\author{
Secondary School Teacher
}

\begin{abstract}
The aim of this paper is to examine how three objects of the past provide the narrator with the opportunity to travel back in time in three different short stories for young adults written by the distinguished Greek children's writer Angeliki Varella. Firstly, I will provide some information about the author and then I will concisely examine how memory works in autobiographical short stories for children and young adults. My objective in this paper is to focus on "Fluri konstantinato" (1998), "Kobe kore" (1999) and "The sounds of the gramophone" (2006). I will trace the journey of memory in these three short stories and I will explore how objects function as vehicles for the narrator's journey into the past. A golden coin (fluri) brought by a refugee from Asia Minor in "Fluri Konstatinato", a bakiri - a cup for carrying porridge- in "Kobe Kore", an old gramophone in "The sounds of the gramophone", all these objects of another epoch, exist simultaneously in the present of the narrator, not only as decorative elements, but also as reminders of her childhood. In these three autobiographical short stories the narrator's past comes alive through memory, and memory continues to recall experiences as things of the past are still there, having their own 'voices'. The role of the objects and the confrontation with figures of the past in each story will therefore be analyzed. I also hope to show the aspects of the articulation of time and space through narrative modes in these three stories.
\end{abstract}

Key- words: Angeliki Varella, autobiographical short stories, Children's literature, childhood, journey of memory, narrative, past. 


\section{Introduction: The author for children Angeliki Varella}

Angeliki Varella (1931-) is one of the most important contemporary Greek authors for children. She has been an indefatigable visitor to schools and a committed children's literature author over the last fifty years. Her first book was published in 1966 and from then on her writing has appeared regularly in children's literature. She has been celebrated by children, by teachers and by children's literature critics. Angelliki Varella's three great loves are: children, books and travelling and as she herself mentions all her life has revolved around them. Her literary work covers a broad range of topics and approaches to various issues. However, a recurrent theme that has emerged in her texts is the love for objects belonging to the past. An "object which existed in the past and exists still in the present', acts on her memories, reminding her of the past and becomes for her "the point of origin for narrative" (Stewart, 1993:136), creating “a continuous and personal narrative of the past"'( Stewart, 1993:140).

Psychoanalyst D. W. Winnicott recognizes the complexity and the importance of objects to children and to the development of their imagination and language (Winnicott, 1980: 28-32). Yet, it can be said that not only children, but also people of all ages can be linked with objects of the present or of objects belonging to the past. "How much do we love these old lifeless (are they really lifeless?) objects which keep us company in daily life..." says the narrator in one of Angeliki Varella's stories in the book Ten sandwiches with stories (Varella, 2002:34 ).

In this paper we will examine the identity of the narrator, one of the central concept in the analysis of narrative texts $\left(\mathrm{Bal},{ }^{2} 1997: 19\right)^{1}$ and the role of objects in three short stories written by Angelliki Varella. These three stories written by her are chosen as, in all of them, objects with their "voices" contribute, to a higher or to a lower degree, to the activation of the narrator's memory. Each of these autobiographical short stories focuses on a different object, however all of them belong to anthologies, to literary works written for young adults that can also be read by both children and adults. In each of them a story is recounted, based on actual events of the author's

\footnotetext{
${ }^{1}$ In the same work it is also added that the narrator and the choices implied give the text its specific character.
} 
childhood. Similarities among the three are apparent, mainly concerning the place, the persons involved and the time, and "by time we here mean the actual time when the events happen, not the duration and other temporal components of the narrative" (Nikolajeva, 2005: 127).

As Andreas Karakitsios notes, memory plays a vital role in autobiographical short stories for children, while the feelings of loss and of the nostalgia of childhood are prevalent (Karakitsios, 2010:64). The descent into the past, according to him, is related to the narrator's childhood (Karakitsios, 2010:126). The events of the autobiographical stories have occurred in the narrated distant past, the historical atmosphere of which is "created by interior and exterior descriptions, clothes, food, people's ways and habits" and "a sense of place" is "enhanced by concrete details"(Nikolajeva, 2005:132). Autobiographical writing is a reconstructive and dynamic process that offers the opportunity of travelling back in time, thus it is

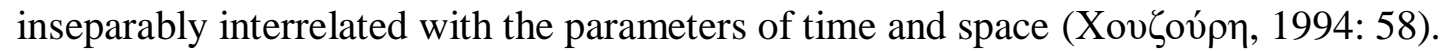

In autobiographical writing memory- cultural or personal- functions as a source of human identity and it is activated through the senses, through acoustic and visual images or through the sense of smell. However, there are simple, everyday objects of the past, whose pictures are so fixated on our minds, thus becoming the motivating force for the journey to the past ( $\mathrm{B} \lambda \alpha \beta$ เ $\alpha$ vov́, 2011: 365).

\section{Methodology}

In order to analyze the contents of the stories and to investigate its structures and its fictional devices, it is helpful to build on the fundamental blocks of the theory of narratology and specifically on Figure III (1972) by Gerard Genette. Gerard Genette's work is of paramount importance for those who are interested in narrative theory itself, because it is one of the central attainments of what was called "structuralism". The structuralists' project was to develop a poetics which could stand to literature, as linguistics stands to language, and which would attempt to reveal the system of figures and conventions that enables works to have the forms and meanings they do. Gérard Genette offers a clarification, systematization and extension on tense (temps), mood (mode) and voice (voix). Under the verbal category of tense he examines all 
temporal relations between narrative and story: temporal order, disruptions of linear chronology, duration and frequency of representation. Under mood he deals with the mode of representation: distance and perspective, while within the category of voice he distinguishes the differences between "narration" and "focalization".

To explore the relations between the narrator and the objects, we have to focus mainly on the category of voice, and specifically on the following questions: "Who speaks?"and "How the narrator is connected with the narrated events?" In a narrative text, an agent relates a story in a medium; that is, a narrator utters the signs. When analyzing a narrative text, we use to examine "what" is said and "how" all of this is narrated. According to Mieke Bal, two types of speakers are detected in a narrative text: the narrator and the actor. Even to first-person narrations, the person who does the talking and the person who acts are distinguishable, as the narrator is the same person, but at another moment and in another situation than when s/he originally experienced the events (Ball, ${ }^{2} 1997:$ 5-9). As Andrea Schwenke-Wyile asserts, the narrator-protagonist may narrate events of a distant or an immediate past (SchwenkeWyile: 1999).

Genette distinguishes four types of narratives according to the narrative level of the narrator and his relation to the story: 1. Extradiegetic- heterodiegetic, when the narrator, a narrator of first level (a narrator outside the story world), is absent from the story he tells, 2. Extradiegetic-homodiegetic, when the narrator tells his own story from outside the fictional universe of the text, 3. Intradiegetic- heterodiegetic, if the narrator of second level (within the narrative) relates a story in which he does not participate, 4. intradiegetic- homodiegetic, if the narrator appears as a character in the narrative he is recounting (Genette, 1997).

\section{“Fluri Konstantinato" (1998)}

The short story "Fluri Konstantinato" published in 1998 belongs to the collective work Lost homelands in our souls. The volume is comprised of fourteen stories about the lost Greek homelands of Asia Minor, about "the pain and the nostalgia" of the uprooting (Kontoleon, 2000:18), written by members or friends of the Women's 
Literary Team, a group of women who have offered a great deal to the development of children's literature in Greece (B $\alpha \rho \varepsilon \lambda \lambda \alpha ́$, 1987:154-155).

In this story, the author's adoration for objects of the past is initially revealed in the introductory note, when she explains her relationship with the "lost homelands" and makes use of two objects- not mentioned in the story: an old carpet and a charcoal fireplace. The last one is used metaphorically as well, as it is said that its flame follows the author in her life (Varella, 1998: 28).

The story consists of two parts in which both the narrator does not inhabit the storyworld ("extradiegetic-heterodiegetic" narrator, Genette, 2007:324). In the first part the omniscient and omnipresent narrator records an episode from the childhood of Vaitsa, who is the main character of the story, while in the second from her adulthood.

In the first part little Vaitsa is sick with fever, therefore she cannot be together with the children of her neighborhood, who play a game and sing its song about a golden coin. It is a song about a "fluri', a golden coin from the time of Byzantium, mentioned already in the title, which seems to be an intertextual phrase taken from this two-lined dialogue song of the traditional children's game. In the first line of the dialogue- song the object is mentioned:

"We got from you a fluri konstantinato - a valuable coin",

"You got from us a bottomless barrel (an empty barrel or something of minor importance)"' (Varella, 1998: 29).

The sick girl is waiting for aunt Artemula ${ }^{2}$, who is her godmother, to tenderly touch her throat, to check her tonsils, to make her well by using traditional remedies, such as they used to do in her homeland, in Smirni in Asia Minor. Aunt Artemula, a refugee from Asia Minor, is being described and the reader understands that she appears to have won the heart and mind of Vaitsa with her kind behavior, with her storytelling (intradiegetic - heterodiegetic). As Bal notes there are three senses which are

\footnotetext{
${ }^{2}$ The exact relationship is not mentioned. Even though the use of the word "aunt" is common in Greek traditional communities as a prosonym (Triantou, 1997:83), the story is autobiographical and according to the author's biographical information, her godmother was her aunt.
} 
especially involved in the perceptual representation of space: sight, hearing and touch (Bal,1997:133) and in this story all three participate in the presentation of space.

During her visit the girl takes a nap but later as she opens her eyes, she sees her mother and aunt Artemula holding each other's hands. But there is no beauty on her aunt's face. She looks quite different and she is whispering to her mother things that sounded like instructions for her funeral. Readers, in a time synopsis (Genette, 2007: 173), are informed that although Vaitsa recovered, aunt Artemula soon died. Vaitsa and her friends in the neighborhood decided not to play again this game, neither to sing its song.

In the second part of the story the setting is the same; with the reader finding Vaitsa in the same house, in the same neighborhood; only time has changed. The flow of time is indicated by the phrase "Years passed" and by the repetition of the song of the traditional game. Again children are playing and performing the song of the game. The actual song verses stand in time and continue to be sung by children in spite of the "cruel hand" of time. This time not by Vaitsa's friends, but by the friends of her daughter, as she is a mother herself. Now it is Vaitsa' s daughter who is absent, missing from the children's company. She is sick with fever and her mother is waiting for the doctor. Meanwhile she takes off her golden coin pendant and puts it on her daughter's neck. Thus, the golden coin, the "fluri", which is mentioned only in the song sung by the children of the neighborhood in the first part, now appears to be a real object.

A "fluri constantinato" is a coin bearing the imprint of the first byzantine emperor, Constantine the Great, of his mother and of the cross. The role of this coin is more complicated and symbolic. As Henry Maguire notes "pierced coins were worn not only for their beauty, but also for their inherent powers" as they were believed "to be effective against all diseases and to avert evils of all kinds in early and in late Byzantium" (Maguire, 1997:1041). The potency of coins, this "continuing fascination with the special power of old coins" (Maguire, 1997:1044) survived in the following centuries in the tradition of Greek people. The narrator gives in direct speech the words said by aunt Artemula to her little niece: "With this amulet, you have to fear nothing. It cast spells, it stops bleeding, it cures everything"' (Varella, 1998: 32). Aunt 
Artemula's words are said in direct speech as Vaitsa brings into her mind the words of her beloved aunt, in a folk idiom, an idiom of a dialect of Greek spoken in Smirni in Asia Minor, in order to reveal her origins.

Even the doctor, when he catches a glimpse of the pendant coin, asks in direct speech, so as to get to know more about it and its use. Vaitsa, has the chance to relate about it. It was brought secretly with some other jewelry under her godmother's garments when she left her home as a refugee, she explains. For she could bring nothing else with her as she fled to a new land. Vaitsa's daughter, as the doctor reassures her, is going to get better. This time also the sick child will recover as Vaitsa herself had recovered during her childhood, but now not by traditional remedies, but by the medicine prescribed by the doctor.

The story closes cyclically with the same children's song, like the cycle of life that continues in "its magic continuation" (Varella, 2009:24), enchanting people relentlessly. The game song is repeated four times in total, twice in each part of the text, so that the story initiates and closes with it. Time is presented as a natural cycle while its passage seems to be irrefutable.

The narration is focused on two different points in Vaitsa's life. The common thing is the picture of a girl-firstly Vaitsa and then her daughter- being sick and not participating in the traditional game played by the children of the neighborhood. Nevertheless, there is also something more to be said. It is aunt Artemula's forceful abandonment of her native land and her illness as well. Very much in contrast to little Vaitsa or her daughter, aunt Artemula never recovers. It's only she who is missing, however there is the golden coin hanging around Vaitsa's neck reminding of her aunt's presence and transferring her voice: "What if aunt Artemula had died a long time ago. She heard her speaking to her"' (Varella, 1998:32).

The relationship between the two figures is not interrupted, the connection to the past is achieved owing to an object, a "fluri konstantinato". This coin is significant not only for being gold or blessed, nor only for its "powers", but because it functions as a connective link between previous and successive generations. It links aunt Artemula to her previous homeland, as it was one of the precious things she had brought secretly under her garments when she was compelled to abandon her home. It also 
connects Vaitsa to her aunt who is a member of a wealthy family- its wealth is being indicated by the quantities of golden coins belonging to her- that has its origins in Asia Minor. It even becomes for the main character the means to treasure the memories of a beloved person and the part related to her family background. Moreover, what lurks behind the words of the song of the game repeated in the story is a faint idea that the refugees' homes were seized in 1922- when the Asia Minor catastrophe culminated in the uprooting of thousands of people, while their land was taken, their souls and memories were not, as they were treasured in little portable objects, in personal belongings of their cultural heritage.

\section{“Kobe kore” (1999)}

The short story "Kobe kore" belongs to the anthology of stories In my old neighborhood which was published in 1999 by the Women's Literary Team.

Angeliki Varella in this story, deals with the presence of an enigmatic figure in the neighborhood of her childhood. In this story the "narrator is participant in the events she recounts, she narrates events in which she takes part'" (Prince, 1982:13), in Genette's terminology, the type of narrator is "homodiegetic" and "extradiegetic", that is "a personal narrator telling about the childhood, outside the story during the narrative act, but is a character in the story' (Gennette, 2007: 324, Nikolajeva, 2005: 184-5).

The story begins with the incomprehensible cries of an unknown beggar who is named after them: “- Kobe Kore, kore mi levanter, kobe kore, kobe kore. He was the most tragic figure, [..] he appeared from nowhere. Where was he living? What was his real name? Nobody knew', (Varella, 1999: 9).

The setting of the story is the main character's neighborhood in Athens, in Aharnon. It is also the neighborhood of Angelliki Varella's late childhood and adolescence. As Nikolajeva explains, setting in children's literature "can have a variety of functions and serve different purposes. At the simplest level it states the place and time of action." However, "details of setting can offer information about places and historical epochs that go beyond the young reader's experience". According to her, "historical atmosphere can be created by interior and exterior descriptions, clothes, 
food, people's ways and habits" (Nikolajeva, 2005: 132). In this story the atmosphere of the German Occupation is created by the description of the beggar and by peoples' reactions to his presence.

The time is concrete, the events occur in the winter of 1942, at the time of the famine. It is a difficult period for most people. The beggar's figure appearing every dusk in the neighborhood presents one more dramatic occasion. Nobody has either the time or the desire to take care of him. Some women of the neighborhood take mercy on him, other neighbors are suspicious of him, whereas children laugh at him. The children do not repent for their behavior even when a woman scolds them, neither when they are near the church of Saint Panteleimon: "Difficult times and each one had to bare with his own misery. We were heartless though we were two steps away, to say, from Saint Panteleimon (Mercyfull) who shares his mercy to everyone" (Varella, 1999 :12).

The story is not obviously divided, nevertheless we can distinguish two parts. The word combination denoting time "one day" works as a transitional link to the second part. The transition becomes also obvious with the shift in the grammar from the narrator in the collective "we" to the personal "I". In the first part the story is related in the first person plural and here "memory does not recall only personal moments,

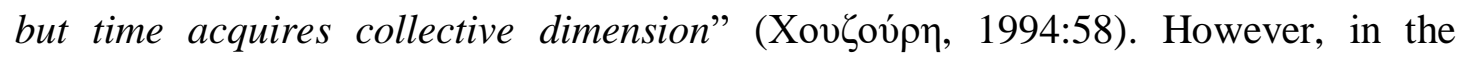
second part the narrator starts relating in the first singular person, talking only about her own experience. Here the young character returns home from the soup kitchens holding the bakiri (a metallic cup) with the porridge when she suddenly comes across the beggar. It is an unexpected meeting as he has changed his usual route. At this point the grown-up narrator's memory is overwhelmed by the sound of a Mendelssohn sonata coming from the piano teacher's house, together with the image of the metallic cup filled with the porridge and the sound of the bell of the tram. All these are mingled in her mind and stuck in her memory for ever. The adult narrator recalls this very moment when she was confronted with Kobe-Kore and the moment when she, as a child, felt remorse for her impertinent action of laughing at him previously.

This is the critical moment of the young girl's maturation. Before meeting Kobe Kore she was indifferent to his drama and showed an attitude of contempt and ridicule, but as she comes across him, she fears him. However, her fear is overcome once she looks 
at him, seeing his figure in a different way. She now realizes his incredible misery: "unshaved, seedy, with wrinkles sculptured on his face, and a chaotic gaze came towards me" (Varella, 1999: 14). Thus, she shows mercy on him and she offers him the metallic cup with the porridge. The last words she heard from him, were his stammered thanks. A few days later she takes a glimpse at his corpse. On the same day she also eats the "asure', a tasty cake and she goes to play in the neighborhood with the other children (Varella, 1999:13).

In the concluding paragraph the adult narrator justifies her behavior, eating the cake and going to play as if it were natural for her age. At this point "engaging narration privileges the voice of the narrating agent, who sees and comments on the actions of the focalizer from a (noticeable) distance at the time of narration'"(Nikolajeva, 2005:190). Thus, the adult narrator gives an explanation that she had obeyed the call of life: "it was life crying out, not myself. A way of life that continued in our little street near Saint Panteleimon" (Varella, 1999: 15).

The object in this story is mentioned in the second part and it is the container in which the narrator used to carry the porridge from the soup kitchens in her childhood. However now, as the adult narrator informs us, it is used as a vase for flowers. Obviously, in Kobe Kore the narrator retains no particular relation to the object, which has no "voice" itself. However, the object is related to the tragic figure of a beggar, a figure of the distant past of the adult narrator. A miserable, unknown man, a representative figure of the dramatic time of the German Occupation, had once touched it on his lips. And it all happened on the day when the narrator as a child realized to some degree the dimensions of the famine as well as the tragic moments of the Second World War.

\section{"The sounds of the gramophone" (2006)}

The third story "The sounds of the gramophone" is one of the twenty three stories of an anthology with the title Extinct Professions also written by authors belonging to the Women's Literary Team. In this story Angeliki Varella gives information about 
the job of a gramophone repairer as well as the job of an antique shop owner. The story begins as follows:

"No. I shall keep the little box. Anyway how much room does it hold a box for gramophone needles?' '(Varella, 2006: 23). It is the homodiegetic narrator's statement that she is not going to throw away the box used for the gramophone needles. In these words the narrator announces her decision, her determination to keep it forever. This object becomes for the narrator the vehicle for recalling events and objects of her childhood. It is worth mentioning that this time the journey to the past is more clearly associated with the object from the very beginning of the narration.

Firstly, the narrator recalls taking the green tram from the stop at Saint Panteleimon's and going to Sintagma and then to Nea Smirni to aunt Artemula's home. At this point aunt Artemula is said to be the narrator's beloved person. It is a similar description to that of her in Fluri Konstantinato, only the words differ: "It was my dear aunt Artemula, my love. Fluffy and beautiful, wearing a lot of bracelets on her wrists, speaking sweetly', (Varella, 2006: 23).

The time of action is not completely concrete, it is all that happens in the 29th of June, the day of the celebration of Saint Peter and Paul, the day when aunt Artemula' $\mathrm{s}$ husband, a printer of magazines of the time, celebrates his name day as his name was Paul. In their home she finds a haven while she has the opportunity to read voraciously in the magazines printed: "The main attraction for me was the library, in which the well stacked books in their crimson colored covers, were waiting for me to browse through, when we got there, I found myself sucked into the world of these novels, with Ioanna Bukuvala's being my first choice"' (Varella, 2006:24). She relishes in reading the sequels of the novels written by Bukuvala, an author born in

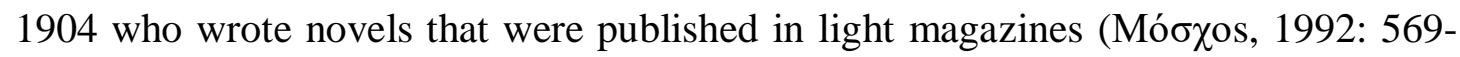
570)

As soon as guests arrive, the young girl is being interrupted and has never the time to read the last two sequels of the novel. These two magazines "before her, closed and unread", will never be "opened to be revealed" (Stewart, 1993:35). Alexandra Zervou notes that the autobiographical picture of a child bookworm is prevalent in 
children's literature. She also emphasizes the importance of the first readings of childhood ( Zervou, ${ }^{6} 2012$ : 139) which can also be applied to this story, too.

In the living-room uncle Peter brought the gramophone. The adult narrator describes it: "And there at the sitting room uncle Peter brought the gramophone and set it up on a coffee table. Its funnel was light blue, with little white flowers, each one with five petals. For the first time in my life I was very close to this magic box and I adored it', (Varella, 2006:24). At this point the girl gets drawn into the dancing and dances with uncle Peter the first dance of her life. That dancing, the half read novel, the gramophone, all these pictures of her childhood stuck in her mind for ever.

In the second part of the story there is a change in time and place. The main character is now an adult who is visiting a shop of a gramophone repairer, hoping to cure her feelings of nostalgia: "Could the old man who was leaned over the table with the screwdrivers, in the dim light of the lamp, to repair the unhealable nostalgia I was feeling, to bring back the people who had left a long time ago, or the invitation to dance by uncle Peter, or aunt Artemula's sweet voice, or the hoarse but so sweet sound of the gramophone singing the song "'Rezenta',[..] or the half-read story?", (Varella, 2006:27).

The narrator wandering among the ten gramophones and mourning the many losses in her life, feels like going back to her past. Suddenly, the place with the gramophones is transformed and becomes a space that gives room to her dreams. It becomes "full of

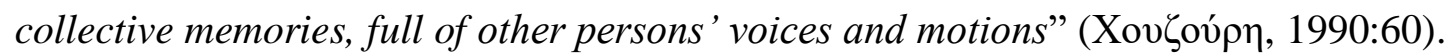

In the third part of the story the narrator explains how the gramophone came into her possession. She came across it accidentally in an antique shop at Kalohori in Salonika. Among all the old things in that shop she takes a glimpse of a gramophone similar to that of her childhood, which all of a sudden becomes "special because of its singularity" (Shannon, 1986:178). Thus, after many wanderings, after many years of absence in a revelatory moment she encounters with it.

Lutz Jäncke says that strong feelings are aroused by the hearing of music as it activates the entire limbic system, "which is involved in processing of emotions and in controlling memory" (Jäncke, 2008: 21). However, the narrator in this case cannot 
hear any music at all.The gramophone, old and out of order, remains mute. It has ceased to function according to its assigned use. Nevertheless, pictures of the past are coming through it and the narrator is being overwhelmed by them. The visual image of an object related to her past enacts the process of recalling. Moreover, this visual image contributes not only to the reconstruction of the visual image of the old gramophone but also to its acoustic images, to its sounds which "could not be any sweeter' (Varella, 2006:26).

But "how does one obtain an object that holds gathered time?"' (Shannon, 1986:179). The narrator gently takes it in her lap intending to carry it to her home, as "it is the honor and reverence with which people treat objects that bring about their full magic of holding time"'(Shannon, 1986:178). The old gramophone in her lap, touching her abdomen, the place from where life starts, gives itself birth to all the figures of the "dead past". Therefore, past and present is mingled with each other and the narrator feels like bringing back the persons of the past, the moments of the past such as the trips from Saint Panteleimon to Nea Smirni.

To suggest the importance of this link between the narrator and the object of the past, the language of the narration becomes more sentimental, more poetic while the voice of the object is clearer. Moreover, it is worth mentioning that in the story "The sounds of the gramophone" the author prefers not to refer to any aspect of the painful past while in the story "Fluri Konstantinato" it is the death of the aunt or even the loss of the homelands that cause sorrow. In Kobe Kore it is the starvation, the presence of the miserable figure of an unknown beggar and people's indifference to him that give the sorrowful picture of a difficult time.

This third story ends with the explanations of the adult narrator about her relationship with the gramophone which is kept as a central element in her cottage and as a central one to her life (Shannon, 1986:178). The friendship that has really developed between them, between the narrator and the old object, involves spending time together, chatting and even physical contact, as she puts her "mouth on its big mouth from where the spirits of childhood come out" (Varella, 2006:29). Yet, the choice of the title "The sounds of the gramophone" reveals the significance of its music and its voice. While in the other two stories the presence of the objects is also connected to three senses (sight, hearing, and touch), here sight and hearing are more emphatically 
connected to the tactile object perception, as the object in this story represents something more, obtaining further symbolic function. Finally, it must be added that the use of the present tense in the two last paragraphs indicates that this friendship will stand against all consuming time, both now and in the future.

\section{CONCLUSION}

The attempt throughout this analysis has been to illustrate the relation of the main character of the three stories with people and objects of the past. Utilizing three autobiographical short stories for children and young adults written by the same author, Angeliki Varella, I tried to present the identity of the narrator and the main character. The main character, who in two of the stories is also the narrating agent, recalls affectionately and longingly times of the past.

In these stories to some degree the triple dialectic of time, space and people are similar and inter-textual (the childhood of the narrator, the old neighborhood, the children of the neighborhood, the figure of aunt Vaitsa who is also the narrator's godmother). However, what is of vital importance is the presence of the objects of the past in each story, which while they are used in a different way according to their utility in the first part of each story, their role proves to be the same in the second part, functioning as a link between people of the past and the present, offering "the sense of a connection with the people of the past"," (Aers, 1970: 70).

In these three stories, objects of the past have their own "voice", and therefore evolve from being just a golden coin, a metallic cup or an old gramophone, " for they come to incorporate and reveal something other than themselves"'(Shannon, 1986:178). They enhance the main character's memories and reveal their power against the corrosive flow of time, change and loss.

In the last story of the anthology Extinct Professions, titled "My enemy, the junk dealer' written by Lia Hatzopoulou, another member of the Women's Literary Team, the main character seems to hate the junk dealer, "because he takes away from people objects which should be kept to remind them past moments of their lives", (Hatzopoulou, 2006:224). In this respect, attention is to be focused on what is being 
hidden within the world of our old, useless objects which may be of use if we let them "act on our memories"' (Aers, 1970:70). 


\section{REFERENCES}

\section{PRIMARY SOURCES}

Hatzopoulou, L. (2006). My enemy, the junk dealer. In The Women's Literary Team,

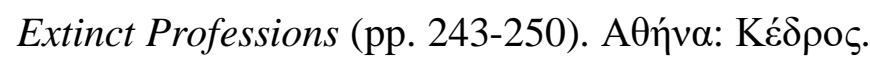

Varella, A. (1998). Fluri konstantinato. In The Women's Literary Team, Lost

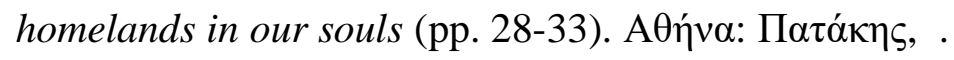

Varella, A. (1999). Kobe kore. In The Women's Literary Team, In my old

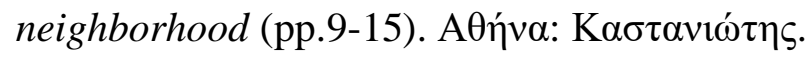

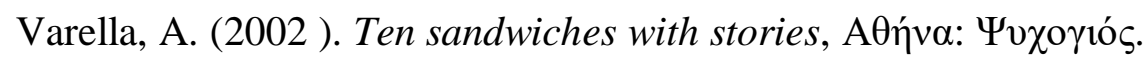

Varella, A. (2006). The sounds of the gramophone. In The Women's Literary Team,

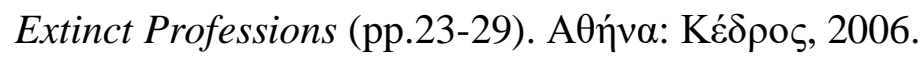

\section{REFERENCE BOOKS}

Aers, L. (1970). The Treatment of Time in four Children's Books. Children 's Literature in Education, 2, 68-81.

Ball, M. ( $\left.{ }^{2} 1997\right)$. Narratology. Introduction to the Theory of Narrative, (Christine van Boheemen, transl.). Toronto: University of Toronto Press.

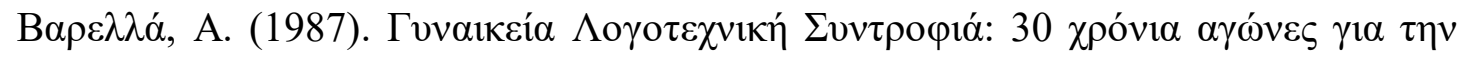

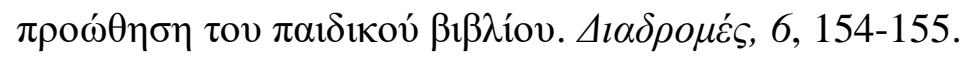

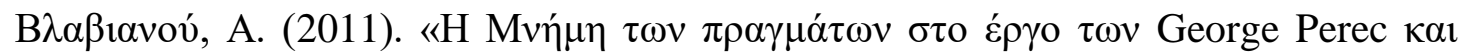

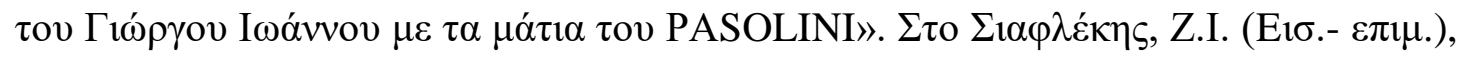

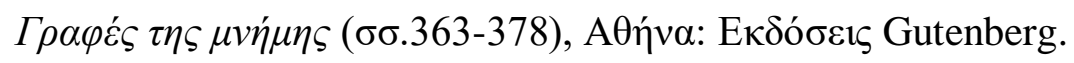

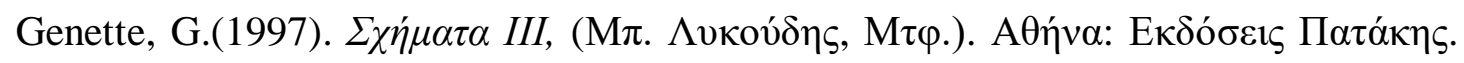

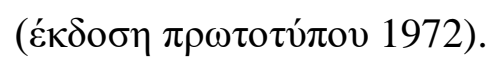


Jäncke, L. (2008). Minireview Music, memory and emotion. Journal of Biology, 7, 21.

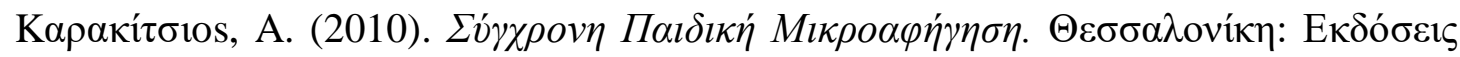
Zvүós.

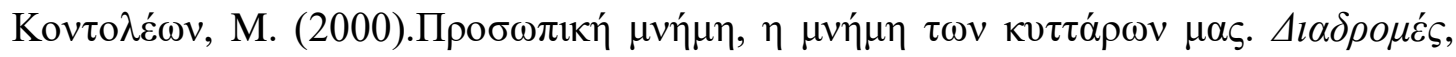
57, 17-19.

Maguire, H. (1997). Magic and Money in the Early Middle Ages. Speculum, 72 (74), 1037-1054.

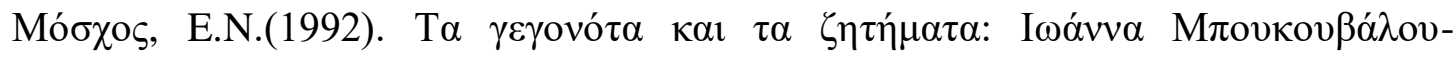

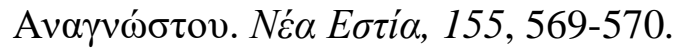

Nikolajeva, M. (2005).Aesthetic Approaches to Children's Literature. An Introduction. USA: The Scarecrow Press.

Prince, G.(1982). Narratology: The form and the function of Narrative, Berlin: Mouton.

Schwenke - Wyile, A. (1999). Expanding the View of First-Person Narration. Children's Literature in Education, 30 (3), 185-202.

Shannon, G. (1986). All Times in One. Children's Literature Association Quarterly, $10(4), 178-181$.

Stewart, S.(1993). On Longing. Narratives of the Miniature, the Gigantic, the Souvenir, the Collection. Durham and London: Duke University Press.

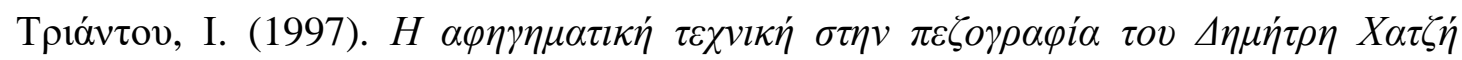

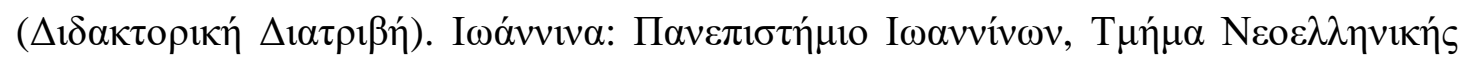

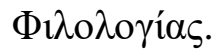

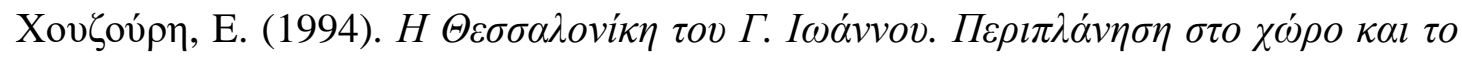

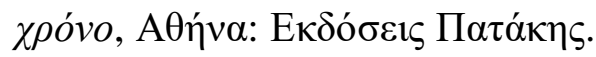

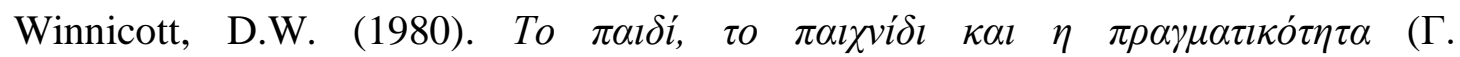
К 
Wyile - Schwenke, A. (1999). Expanding the view of First -Person Narration. Children's Literature in Education, 30 (4), 185-202.

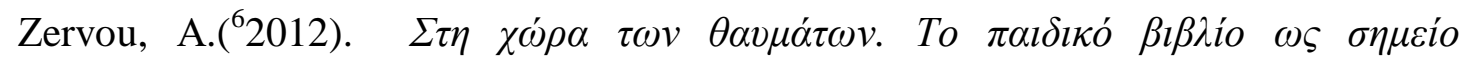

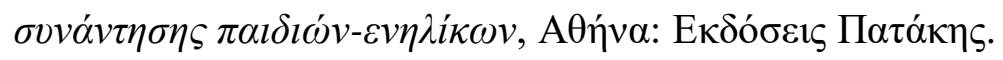

